\title{
The Poetics of Adaptation in Frankenstein in Baghdad
}

\author{
Asst. Prof. Raad Kareem Abd-Aun ${ }^{1}$, Asst. Lec. Ameer Abd Hadi ${ }^{2}$
}

\begin{abstract}
During the peak of the sectarian war in Iraq after the US invasion in 2003, there seemed to be an absolute absence of the mind and a great deal of hatred and tension among the people of Baghdad that turned into maddening acts of terrorism, like car bombings and suicide bombers, killing thousands of innocent people. Frankenstein in Baghdad came to be the mouthpiece of that very critical phase in the modern history of Iraq. The abundant acts of killing and bloodshed during 2005 turned into an ugly form of a monster called " Whatsitsname" formed from the fragmented parts of those killed by terrorist acts. The creature bears a clear resemblance to Marry Shelley's monster in her novel Frankenstein. The monster is a loose perpetrator that kills whoever it meets. This study attempts to analyze the writer's poetics of adaptation in the novel and his debt to other literary works.
\end{abstract}

Keywords: Frankenstein; Baghdad; Poetics; adaptation; Shelly; Saadawi

Article Received: 18 October 2020, Revised: 3 November 2020, Accepted: 24 December 2020

\section{Poetics and Adaptation}

Poetics is a theory of literary forms that is concerned with the text's different elements that come together and create certain effects on the reader. It goes beyond the literal meaning of the text to its dramatic representations. In other words, it is the writer's craft and tools that serve his narration in a certain theme to produce a verbal message. (Genette, 2005) Adaptation, on the other hand, is "the process by which one narrative form or medium is converted into another" (Cuddon, 9) as, for example, the graphic novel Watchmen and its film adaptation. Sometimes the same work is adapted into the same medium, like Shakespeare's King Lear and The Tempest and Bond's Lear and Cesaire's Une Tempete.

The last two examples of adaptation are of interest. Slavoj Zizek states that "the only way to be faithful to a classic work is to take such as risk [ie, adapting, changing, it] - avoiding it, sticking to the traditional letter, is the safest way to betray the spirit of the classic. In other words, the only way to keep a classical work alive is to treat it as 'open', pointing towards the future". (xii) A classic is a classic because it allows itself to be read by every generation and mean something new to each.
Ahmed Saadawi's Frankenstein in Baghdad is loosely based on Mary Shelley's Frankenstein; or, The Modern Prometheus from which Saadawi takes the idea of the reanimated stitched up corpse and recasts it in a modern-day civil war torn, USinvaded Iraq. Such an adaptation allows the writer to indulge in creating new characters and a new storyline that, by being different from the original work, not only gain new nuances of meaning, but impregnate the original with meanings that are (yet) to be seen.

\subsection{Ahmed Saadawi and Frankenstein in Baghdad}

Ahmed Saadawi is an Iraqi novelist, poet, documentary film maker, and screenwriter. $\mathrm{He}$ was born in Baghdad in 1973. He wrote Anniversary of Bad Songs, a collection of poems, in 2000. In 2004, he wrote his novel The Beautiful Country, followed by Indeed He Dreams or Plays or Dies (2008). In 2013 he published his most celebrated novel Frankenstein in Baghdad. The novel received The International Prize for Arabic Fiction (IPAF) in 2014, France's Grand Prize for Fantasy, as well as being shortlisted for The Man Booker International Prize in 2018, plus other local prizes. The novel has been published by Penguin Press in 2018. He published another novel. The Chalk Door (2017), and The Naked 
Face Inside the Dream, a collection of short stories (2018).

The novel is set in Iraq in 2005, and begins with a top-secret memo written by an Iraqi intelligence committee investigating the Tracking and Pursuit Department, a bureau that employed astrologers to predict the locations of future terrorist attacks. The novel then flashes back several weeks, focusing on the Baghdad neighborhood of Bataween and some of its residents. One of the residents of Bataween is Elishva, an old Assyrian Christian woman, who still hopes for the return of her son Daniel, who went missing while serving in the military during the Iraq-Iran War. Another is Hadi, a junk dealer and storyteller, and Mahmoud, a young journalist, who gets involved with Hadi and his story about the Shisma, or Whatsitsname. Hadi is mourning the death of his friend, Nahem Abdaki, who is killed in a car bombing several days before. After Abdaki's death, Hadi goes to the morgue to claim his friend's body, only to discover body parts strewn all around the facility. Hadi decides to collect body parts from car bombings and stitch them together so Abdaki's family would have something to bury. He leaves the corpse in the courtyard behind his house. After another car bombing, Hadi finds a nose in the rubble, the last piece he needs for Abdaki's body. Later, Hadi witnesses yet another car bombing when a garbage truck drove into a hotel gate, killing the guard inside a booth at the gate, a young man named Hasib Mohamed Jaafar. After the bombing, Hasib's soul drifts through the city seeking his body, and instead finds the corpse in Hadi's courtyard. Hasib's soul inhabits the body and the body becomes sentient.

In a coffee shop, Hadi tells the story of the corpse to a group of people but they make fun of him. Among the people in the coffee shop is Mahmoud the journalist. Mahmoud works at a magazine under an editor named Ali Baher al-Saidi, whom he views as a father figure. Mahmoud wishes to be just like his mentor. Meanwhile, the now reanimated corpse visits Elishva, and she believes it is her son Daniel, returned to her at last.
The next day, there were a series of murders in Bataween, and one of the victims was the local barber, Abu Zaidoon, the man who forced Daniel to join the military, and whom Elishva blames for her son's disappearance. Witnesses described the perpetrator as a hideous man with a "mouth like a gash across his face" (86). The Tracking and Pursuit Department begins an investigation into the crimes, fronted by its leader, a man named Brigadier Majid. Hadi tells Mahmoud that the corpse, whom he names Whatsitsname, visits him and explains that he is on a mission to avenge the deaths of the people whose various parts made up his body. Mahmoud gives Hadi his digital recorder and instructs him to conduct an interview with Whatsitsname. Mahmoud then writes an article about the creature. In response to the article, Brigadier Majid calls Mahmoud's boss and demands to know more about Whatsitsname, but Saidi assures him the story is a hoax.

Hadi returns Mahmoud's digital recorder, now featuring a long monologue by Whatsitsname about his recent troubles. On the run from the law, the creature hides in an abandoned building in Dora, a neighborhood in southern Baghdad. There he attracts numerous followers who believe him to be sent by God to save them. Whatsitsname discovers that, after avenging a death, he loses a body part and has to replace it with another, thus his mission could never end. He even begins killing innocent people in order to keep his body intact. Eventually, his followers' ideological differences result in a war breaking out among them, and all are killed.

Majid interrogates Mahmoud about Whatsitsname, and tells him where to find Hadi. Majid sends his men to Hadi's house, and when the junk dealer could not or would not give up the creature's location, Majid's men beat him. Back at the Tracking and Pursuit Department, Majid talks to his two astrologers. The senior astrologer claims he could locate Whatsitsname, while the junior astrologer claims he could actually tap into the creature's mind. Meanwhile, another car bomb detonates in Bataween. 
The novel's final bombing badly disfigures Hadi, and after being stitched up at the hospital, he looks like his creation. Facing intense pressure to find the murderer in Bataween, police arrest Hadi and claim he is responsible. The people of the neighborhood celebrate the arrest in the streets as Whatsitsname looks on from a window (Saadawi, 2018).

\subsection{Marry Shelley's Frankenstein}

It is to Marry Shelley the invention of the fictional character is attributed. The creature comes to be known as Frankenstein, although it is its maker's name, and not its own. It becomes one of the most celebrated characters in world literature. The spark of the novel comes from a competition suggested by Byron one night when Shelley, Percy, and Byron were trapped in a house because of a stormy weather. The competition was to write the best ghost story. Marry won the competition by her creation of the novel Frankenstein (Badalamenti \& Health, 2006).

The monster is Victor Frankenstein's creation, assembled from old human body parts and strange chemicals, turns into a living creature by a mysterious spark. $\mathrm{He}$ is tall and enormously strong but with the mind of a newborn. He is abandoned by his creator Victor Frankenstein because of his ugly shape. Confused, Frankenstein tries to integrate himself into society but he fails because of his horrifying disfigured appearance. Looking in the mirror, he realizes his physical grotesqueness, an aspect of his persona that blinds society to his kind heart, gentle and innocent nature. The society plants hatred inside him. Realizing his doomed singularity and the society's rejection to him, he starts seeking revenge on his creator, starting a series of killings. First, he kills Victor's younger brother, murders Victor's best friend, and then his new wife. He avoids killing Victor because he feels Victor is like his God.

The monster is an eloquent narrator in the novel and he is not a purely evil being. He shows his remarkable sensitivity and benevolence, assisting a group of poor peasants and saving a girl from drowning. However, he is rewarded only with beatings and disgust because of his appearance. Torn between vengefulness and compassion, the monster ends up lonely and tormented by remorse. Even the death of his creator-turned-would-bedestroyer offers only bittersweet relief (Badalamenti \& Health, 2006).

\section{Poetics of Adaptation in Frankenstein in Baghdad}

\subsection{Preface: Setting up Ambiguity}

The novel opens with a co-report done by a special committee of officers from the Iraqi and US intelligence agencies. The report is about 250 pages long and is not to be published as it is classified. It is leaked from inside the Iraqi Tracking and Pursuit Department. All the documents emailed to a person who is only referred to as "the author". From the beginning of the novel, the reader is triggered by short and vague pieces of information and this arouses her/his curiosity to know what the report is, and what it tells. (Webster \& Medicine, 2018) Furthermore, a committee of investigation recommends to transfer the officers responsible for leaking the report and laying off the astrologers and fortune-tellers who are employed in the department, as well as re-arresting the author for further investigation.

The Iraqi-US intelligence committee officers give authentic touch to the report, whereas the unnamed author, astrologers, and fortune-tellers who are members of the department of intelligence, would scruple the reader's imagination and prepare him for the unknown events to come.

\subsection{Setting (Realism vs. Surrealism) and the Rise of the Monster}

In narratology, a realistic narrative creates a fictional world in which characters, who look like real people, exist and interact with each other in a world that is almost completely the same as the real world in terms of time, place, and acting persona. (Fludernik, 2009) The novel is set in 
2005, and the main part of it revolves around characters from different social and religious backgrounds living in Bataween, a popular old neighborhood in Baghdad. The diversity of the characters mirrors the diversity of the Iraqi society. Bataween has multiple layers of history from Jewish, to Christian, to Muslim. Many inhabitants claim they were original citizens and others came from distant towns in Iraq, but, the narrator argues that nobody knows who is new or original because they have been there for a long time. They all seek to make sense of the new Iraq after the American invasion. (Webster \& Medicine, 2018) The writer wants to say that what is going to happen to the people living in Bataween is going to happen to all Iraqis, regardless of their religions or ethnicities.

Rumors from here and there start to appear about a creature they call "Shisma", a term in the Iraqi colloquial language when someone does not know the name of someone or something, literally it means "Whatsitsname". The people's tales about the monster overlap and contradict and this creates a sense of mystery Saadawi wants to establish in the opening pages of the novel, as in Shelley's novel when Victor refuses to tell Walton about his biomedical queer experiment of creating the monster because first, it is supernatural and, second, it is dangerous. Saadawi furnishes his reader's imagination with the natural only to surprise him with the unnaturalness of the events to come (Bahoora, 2015).

Before presenting Whatsitsname in the novel as a supernatural character who wants to start his "noble mission", and in order to lighten the shift between the normal and abnormal, Saadawi borrows a surreal technique of reanimating the corpse by Hasib's spirit who is killed by another suicide bomber. For the surreal involvement to be more acceptable and convincing, at the day of Hasib's burial, all of Hasib's family dream of their son and their dreams are all incomplete, i.e., each dream fills the gap of another and they all confirm that Hasib's spirit is still hanging around because it seeks rest that it does not find. Saadawi employs dreaming as it is the only (permissible) medium that the living can communicate with the dead according to the Islamic religion. Hence, along with the surreal act of reanimating and the dreams of Hasib's family, Hadi's work is complete (Webster \& Medicine, 2018).

When the creature is whole, i.e., body and soul, he only needs an identity and a call to orient him where to go or what to do. The first thing Whatsitsname does is visiting Hadi's neighbor, the Christian widow Elishva. People in the neighborhood believe that she got mad because she never stops talking about her son Danny as if he were alive. She is certain that in the evening God speaks to her through the image of Saint George on the wall of her living room. Once she begs the saint to tell her anything about her son "whether he was alive and would return or where his real grave or remains were" (p.15). A desperate and devastated character like Elishva is very much ready to believe in any foreign visitor and take him in as Daniel. So, it is Elishva who first talks to him and gives him an identity as her son Daniel. Whatsitsname's first speech reveals a lot about him: (Elayyan \& volume, 2017).

I don't have much time. I might come to an end and my body might turn into liquid as I'm walking down the street one night, even before I accomplish the mission I've been assigned... She's [Elishva] a really poor old woman. They are all poor, and I'm the answer to the call of the poor. I'm a saviour, the one they were waiting for and hoped for in some sense. These unseen sinews, rusty from rare use, have finally stirred. The sinews of a law that isn't always on the alert. The prayers of the victims and their families came together for once and gave these sinews a powerful impetus. The innards of the darkness moved and gave birth to me. I am the answer to their call for an end to injustice and for revenge on the guilty. (136-7)

With body, soul, and noble reason, Whatsitsname begins his mission. A creature born out of killing and bred on killing, who leaks viscous liquids and oozes out blood, breaks the rules of nature and society. 
Whatsitsname can be read as a metaphor of the whole Iraqi society. It is a hybrid character composed of different body parts that belong to Iraqi citizens from different religious backgrounds and ethnicities stitched together into a disfigured combination because it is created out of hatred and conflicts among Iraqi people. It is a "nation" that is "fragmented and injured".(Bahoora, 2015) Furthermore, Whatsitsname can be read as an international character, i.e., wherever there is an internal conflict in any society in the world, there is Whatsitsname, or Frankenstein, nourished by the blood of the civilians killed by the conflicts, and once the conflicts and bloodshed stop, that monster passes away. (Webster \& Medicine, 2018).

Annie Webster argues that Whatsitsname, though it is not a "coherent individual", (448) represents a symbol of salvation to the victims who have been killed and remained fragments without name, without identity, and unacknowledged. He refers to the loss of identity. He is a symbol of the forgotten people.

\section{The Assistant Characters}

"I have a number of assistants who live with me. They have banded together around me over the past three months." (137) Technically speaking, in order for Whatsitsname to commence his mission, he needs assistants and supporters. The writer employees six characters (The Magician, The Sophist, The Enemy) and (small Madman, big Madman, and biggest Madman). In the peak of the clashes of the sectarian war in Dora neighborhood, these characters help and support Whatsitsname to let him continue fighting and killing people. Each time he loses a part of his body, he begins to weaken, so they cut parts from the bodies of the killed militia fighters and add them to his body. The Magician is responsible for making sure of Whatsitsname's safety during his moves in Dora, and other parts in Baghdad. The Sophist makes plans and explains ideas for Whatsitsname: "I consult him when I have doubts about some course of action. He makes everyone feel reassured and strengthens their faith". (139)
The Sophist is like a spiritual guide for Whatsitsname. The Enemy provides Whatsitsname with important military information and he makes a "living example of what the enemy looks like and how the enemy thinks and behaves." (140) Whereas the rest three Madmen give logistic support, such as dragging the killed bodies, washing blood, stitching body parts into Whatsitsname, etc. (Jani \& -, 2016) One of the passages of the novel clarifies the whole process: "They [the three madmen] dragged away the body of the man who had died bravely, leaving the body of the man who had pleaded for his life - we called him "the saint" ... 'The eldest madman cut out the rotten parts of my body, and the other two madmen - the young one and the elder one stitched in the new parts. Then they all carried me to the bathroom on the top floor, where they washed off the blood and the sticky plasma fluids and dried me. The Enemy gave me the uniform of a US special forces officer and some identity papers. Then the Sophist set about applying a thick layer of women's foundation cream to my face and gave me a mirror. I looked but didn't recognize myself. I moved my lips and realized the face was mine.

"What happened?" I asked.

"We've brought you back to life," said the Magician." (145)

The presence of those six characters with Whatsitsname implies a symbolic connotation that he is a monstrosity created and nourished by certain characters from within the society and without whom it falls apart and dies. In other words, Saadawi thematizes the sectarian violence into two classes, i.e., the planners (Magician, Sophist, and Enemy) and the followers (the three Madmen). (Abdalkafor, 2018) This is clearly stated by Whatsitsname: "My list of people to seek revenge on grew longer as my old body parts fell off and my assistants added parts from my new victims, until one night I realized that under these circumstances I would face an open-end list of targets that would never end." (146-7) 
Whatsitsname is considered a "true Iraqi citizen" (140) because he is created from the Iraqi mosaic, different religious backgrounds and ethnicities of the Iraqi community, criminal and innocent individuals. Sometimes the rate of criminality increases in his body, due to the replacements from criminal body parts, sometimes it decreases when he is replaced with the innocent victims. For instance, one of the madmen tells him, "Tomorrow he'll tell you you're three quarters criminal, and later you'll wake up to find you've become totally criminal" (151). Later in one of the crossfires between the sectarian militias, he starts losing his eyesight and he can seldom see. He beholds an innocent old man, kills him and takes out his eyes and puts them on (Elayyan \& volume, 2017). As a result of being a hybrid character made of criminals and innocent people, he carries contradictory traits within himself due to his complex biological nature.

\section{Shelley's Frankenstein and Saadawi's} Shisma/ Whatsitsname

Saadawi borrows the idea of a supernatural character as a hero in his novel from Shelley. He succeeds in creating a modern conception of Frankenstein to serve his theme. However, there are some comparable points to be mentioned between Whatsitsname and Frankenstein. He chooses for the creature a plebian father in order to highlight the plight of the common man. Unlike the ambitious Victor Frankenstein, Hadi has a lowly job: to scavenge through people's junk for housewares and sell them to poor people who cannot afford new ones. He is an outsider, an old man who lives on the margin of society.

Unlike Victor, Hadi is not a scientist. He is a junk dealer known for telling long unbelievable tales when sitting in cafes of Baghdad. His creation is not part of an interest or adventure he pursues, as is Victor, rather he tries to create a body of his dead friend killed in a car bombing in order to bury him in a respectful way (Webster \& Medicine, 2018).

Hadi's goal behind creating Whatsitsname is a noble one. Out of his loyalty to his dead friend
Nahem and as an expression of respect to him, he decides to form a body from different body parts. On the other side, Dr. Victor does not have that intimate relationship with his creature, though he pities him in some places in the novel. In addition, Hadi's act of creation explains why he is the protagonist, an initiator of action in the sense (Arendt, 2013) distinguished between action, labor, and work. (See her The Human Condition, especially chapters III, IV, and V) His decision to act sets him above all the other characters in the story who simply react to his action. He wants to create a grievable life out of the ungrievable beings who were killed and forgotten, a commendable deed by any measure. Hadi's act of creation is his ultimate defense of human dignity, not only for those who died, but also for those who were alive but were, as Simone Weil argues, "an alternative human species, a hybrid of man and corpse" (Balibar, 2015).

\section{Conclusion}

Frankenstein in Baghdad is a modern take on Shelley's novel. Saadawi manages to adapt Shelley's archetypal character and present it in a modern setting. The creation of Whatsitsname is a mixture of realism and surrealism at the same time, it is real as it is created out of real human parts of the killed, while the resurrection is the surreal part of it when the distressed soul of Hasib inhibits the stitched up body that is to become Whatsitsname. The novelist draws a very thin line between realism and surrealism in a smooth shift in between, resorting to religious beliefs among Iraqis based on dreaming.

The intrusion of the assistant characters proves to be a technical means by which the novelist lets Whatsitsname move through the strife-stricken neighborhoods of Baghdad with high military precision. The Magician, The Sophist, and the Enemy support Whatsitsname with plans, prophesy, and military advice. Whereas the three Madmen help him continue his crimes through bandaging his injuries and replacing the damaged parts of his body with those of his victims. Saadawi draws a perplexing image that represents 
the sectarian war. In order not to make him a completely villainous character, Whatsitsname states that he has a "noble mission" (126) which is seeking revenge for the innocent killed in sectarian violence reflecting the confused frame of mind of the Iraqi society of that period whose vendetta does not lead to peace but to more violence and bloodshed. Finally, Whatsitsname can be taken as an international character that appears in any society once conditions are met.

\section{REFERENCES}

[1] Abdalkafor, O. (2018). Frankenstein and Frankenstein in Baghdad: The Sovereign, Homo Sacer and Violence. Postcolonial Text, 13(3).

[2] Arendt, H. (2013). The human condition: University of Chicago Press.

[3] Badalamenti, A. F. (2006). Why did Mary Shelley Write Frankenstein? Journal of Religion and Health, 45(3), 419-439.

[4] Bahoora, H. (2015). Writing the Dismembered Nation: The Aesthetics of Horror in Iraqi Narratives of War. The Arab Studies Journal, 23(1), 184-208.

[5] Balibar, É. (2015). Violence and civility: On the limits of political philosophy.

[6] Elayyan, H. (2017). The Monster Unleashed: Iraq's Horrors of Everyday Life in Frankenstein in Baghdad. AWEJ for translation \& Literary Studies volume, 1.

[7] Fludernik, M. (2009). An introduction to narratology.

[8] Genette, G. (2005). Essays in aesthetics.

[9] Jani, B. J. (2016). Violence as the abject in Iraqi literature: Ahmed Saadawi's Frankenstein in Baghdad and Mary Shelley's Frankenstein. International Journal of Humanities and Cultural Studies (IJHCS) ISSN 2356-5926, 1(4), 321-336.

[10] Saadawi, A. (2018). Frankenstein in Baghdad: A Novel.

[11] Stephens, A. C. (2007). "Seven Million Londoners, One London": National and urban ideas of community in the aftermath of the 7 July 2005 bombings in London. Alternatives, 32(2), 155-176.

[12] Webster, A. (2018). Ahmed Saadawi's Frankenstein in Baghdad: A Tale of Biomedical Salvation?. Literature and Medicine, 36(2), 439-463. 